\title{
The Practice of Shariah Governance in Islamic Banking and Finance: A Study of Islamic Banks in Bangladesh
}

Riazuddin Ahmed and

Mohamad Saifullah Bin Mohamad

International Islamic University Malaysia

\begin{abstract}
This paper aims to study Shariah governance of Islamic banks in Bangladesh. Desk-based research was conducted for this paper to explore the main challenges faced by Islamic banks in the country. Based on empirical studies and newspapers, this paper concludes that there is a lack of a well-defined regulatory and supervisory framework for IFIs to function effectively in line with the tenets of Shariah. This study also finds that the shortage of Shariah scholars remains an impediment to Shariah compliance. The government and the central bank of Bangladesh should pay greater attention to education and training, in addition to creating a national Shariah advisory council to monitor Islamic banking and financial activities in Bangladesh.
\end{abstract}

Keywords: Shariah Governance; Corporate Governance; Islamic Financial System; Regulatory Framework; Islamic Financial Institutions; Bangladesh 


\section{Introduction}

Any financial institution has a fiduciary responsibility towards the interest of its shareholders. Breaches of fiduciary duty typically happen when a fiduciary behaves in a manner which is against the shareholders' best interests, such as failure to keep information confidential, misappropriation of funds, misuse of positional power, misrepresentation or fraud. Poor corporate governance has often been cited by researchers as one of the main causes of financial crises (Joh, 2003; Johnson et al., 2003; Kirkpatrick, 2008). Islamic financial institutions (IFIs) are not different in this regard. Just like mainstream financial institutions, IFIs are not free from the risk of breaching fiduciary responsibilities. The fiduciary responsibility of IFIs towards their clients is to serve their best interest while at the same time complying with Shariah rules.

The institutional environment in which IFIs operate is important for them to implement good governance through Shariah-compliant operations. Characterised by institutionalised bribery and civil unrest, the institutional environment of Bangladesh is different from neighbouring Islamic countries. Bangladesh is both a challenge and inspiration for bankers. One notable example is Grameen Bank, the pioneer of microfinance. The founder of Grameen Bank, Muhammad Yunus has inspired the global microcredit movement. However, Mr Yunus was forced out as director in 2011; four years later, Grameen Bank was set to go under full government oversight as an attempt by the government to increase its control over the bank (Allchin, 2015). Equally, Islami Bank in Bangladesh, which runs the world's biggest Islamic microfinance scheme, has also suffered government intervention since 2017, with an immediate decline in financial performance (The Economist, 2019).

Therefore, the objective of this paper is to explore the Shariah practices and corporate governance of Islamic banks in Bangladesh and to identify the main challenges faced by these banks. To attain the objective of this paper the following research questions need to be answered:

1. What are the principles of Shariah which ensure good Shariah governance?

2. What are the current practices of Bangladeshi Islamic banks which ensure Shariah governance is maintained?

3. What are the key challenges faced by Islamic banks in Bangladesh in ensuring Shariah governance and compliance?

\section{Risk, Corporate Governance and Shariah Compliance}

Good corporate governance is crucial to all organisations, especially financial institutions. Claessens (2006) found that good governance leads to lower cost of capital, greater returns on equity, higher efficiency and an increased level of confidence for all stakeholders. A particular feature in respect of Islamic financial services is Shariah

International Journal of Management and Applied Research, 2019, Vol. 6, No. 4 
compliance, which means that an Islamic financial institution (IFI) must make sure that their financial products operate in conformity with their religious beliefs.

While Shariah practices differ across Islamic financial jurisdictions, ethical investment is paramount for Islamic banking and finance. Apart from the strict prohibition of riba (interest), gharar (uncertainty), maisir (gambling) and haram (illegal or harmful), Islamic financial products are characterised by the principle of risk-sharing. Central to Islam is the concept of Tawhid, the oneness of Allah (God). Muslims are expected to follow a way of life that submits to Allah in accordance to Shariah law and the teachings of the Quran. Islamic Financial Institutions (IFIs) are no exception. The conceptual foundations and banking practices derived from the above mentioned principles pose challenges to regulators with regard to accounting and documentation standards. Moreover, pressures to tighten the net of prudential supervision emerged after several cases of distress, namely the collapse of Ihlas Finance House (IFH) of Turkey in 2001 and the Tabung Haji scandal in 2018. More often than not, these financial scandals were facilitated by poor corporate governance, where boards fail to manage potential risks or engage in reckless risk-taking behaviours themselves (OECD, 2014). Poor corporate governance in IFIs shares features with other non-Islamic banking scandals, such as mismanagement, audit failure, weak public policy and neglect of minority shareholders' interests (Grais and Pellegrini, 2006b).

Competing with conventional (non-Islamic) financial institutions in dual banking systems, IFIs are subject to the same legal systems as conventional financial institutions despite the fact that the nature of Shariah law is totally different. In addition to the difficulty in enforcing Islamic financial instruments in certain legal environments (Karim and Archer, 2011), IFIs are exposed to default risk, liquidity risk, market risk, credit risk and Shariah non-compliance risk. In the case of default, IFIs are typically prohibited from charging penalties because such a practice is not Shariah-compliant. Such default risk is unique to IFIs and typical solutions mitigating this kind of risk include additional collateral and personal guarantees (International Monetary Fund, 2018). However, the inability to impose penalties creates delays in repayment thereby increasing loss of opportunity cost for IFIs. Besides default risk, IFIs are also exposed to liquidity risk due to the tendency to hold excessive cash reserves (Karim and Archer, 2011; International Monetary Fund, 2018). Furthermore, IFIs use prudential measures that were designed for non-Islamic banks to manage market risks (International Monetary Fund, 2018); however, the complexity of Islamic financial services and products increases reliance on commodities and cash collateral which may exacerbate credit risks (Karim and Archer, 2011). Additionally, Shariah non-compliance is a risk that is unique to IFI, which occurs when an IFI fail to comply with the Shariah rules and principles.

International Journal of Management and Applied Research, 2019, Vol. 6, No. 4 
For these reasons, it is important for the board to review corporate risk policy and ensure that appropriate mechanisms are in place for effective risk management. OECD (2014) articulated the responsibility of the board in managing risk effectively by stating that: "boards have an essential responsibility setting the risk policy by specifying the types and degree of risk that a company is willing to accept in pursuit of its goals" and it is essential for boards to ensure "the integrity of the essential reporting and monitoring systems will require the board to set and enforce clear lines of responsibility and accountability throughout the organisation" (Principle VI.D).

\subsection{Corporate Governance in Islamic Banking}

Previous research on the corporate governance of IFIs is limited but growing. Grassa and Matoussi (2014) studied the practice of corporate governance in Gulf Cooperation Council and Southeast Asia countries and concluded that there are significant differences between the two in terms of governance structure and Shariah board attributes. The Shariah board is an independent body which reviews and supervises the activities of IFIs. According to Grassa and Matoussi (2014), the size of the Shariah board in Southeast Asia is slightly larger and more diverse than in GCC countries. Moreover, the presence of foreign investors and institutional investors in Southeast Asia is higher than in GCC countries (Grassa and Matoussi, 2014). The study of Grassa and Matoussi (2014) is consistent with the earlier finding of Hassan (2011) which concluded that Shariah practices and governance system differ across national boundaries. Furthermore, Hassan (2011) also identified weaknesses of the existing governance framework used by IFIs. Similarly, Grais and Pellegrini (2006b) analysed the shortcomings of corporate governance arrangement in IFIs and recommended solutions to overcome these shortcomings.

\subsection{Shariah Governance}

Shariah compliance is the cornerstone of the Islamic finance industry and thus Shariah governance is no less important than corporate governance for IFIs. The Islamic Financial Services Board (IFSB) defines the Shariah governance system as " $a$ set of institutional and organizational arrangements through which IFIs ensure that there is effective independent oversight of Shariah compliance over the issuance of relevant Shariah pronouncements, dissemination of information and an internal Shariah compliance review" (IFSB, 2009, p. 2). This definition raises three main issues for Shariah governance: independence, accountability, and transparency.

The first issue concerns independent oversight. Each IFI has in-house religious advisers who provide consultation and supervisory services to the IFI as part of the internal governance structure of the IFI (Grais and Pellegrini, 2006b). In principle, the Shariah board is an independent body which reviews and supervises the activities of the IFI. However, there is a potential conflict of interest (Grais and Pellegrini, 2006a) between

International Journal of Management and Applied Research, 2019, Vol. 6, No. 4 
the members of the Shariah board and the IFI because their advisory and supervisory services are remunerated by the IFI which appointed them at first place. Furthermore, such remunerated arrangements may create a symbiotic relationship between the scholars and the IFI that could undermine credibility. The agency problem can be overcome by certification by external reputable auditors and involving self-regulatory Shariah associations to protect integrity (Grais and Pellegrini, 2006b).

The second issue concerns the accountability of the IFI, which can be observed in institutional and organisational arrangements. The board of directors is accountable for all decisions made by the board and thus the board should ensure that internal control system is adequate (Grais and Pellegrini, 2006a). Corporate governance mechanisms are designed to mitigate potential risks by applying appropriate countermeasures and limiting misconduct to serve the best interests of the shareholders in the long-term. These arrangements include appointment of a Shariah board, investment risk reserves and special supervisory attention (Grais and Pellegrini, 2006b). A special risk investment reserve, for example, is used for compensating investment loss.

The last issue relates to the disclosure of all relevant information regarding Islamic finance operations. In addition to improved transparency and increased confidence of stakeholders, disclosure could be the means to address public concerns over financial stability. Ideally, a transparent financial institution would disclose the process of review and decision-making, the composition of its Shariah board, as well as publishing fatwas issued by the committee of the Shariah board (Grais and Pellegrini, 2006a). The openness of IFIs to disclosure of relevant information would strengthen the confidence of stakeholders and investors and enhance their credibility.

\subsection{Shariah Governance Framework}

A framework that guides IFIs to implement good governance is essential in undertaking Shariah-compliant operations. Haqqi (2014) believes that a comprehensive Shariah governance system is based on the following four pillars: first, management and supervision; second, the Shariah Advisory Board; third, Shariah compliance and review, and lastly, transparency and disclosure. Arguably however, these four pillars are more about the past than the future because there is an absence of research and development of this topic.

Grais and Pellegrini (2006a) suggested a combination of external and internal arrangements that can jointly provide an effective framework to assess and monitor Shariah compliance. The internal control system includes a Shariah board which plays an advisory and supervisory role whereas the external arrangement covers regulatory control, standardisation and an audit firm. The framework proposed by Grais and Pellegrini (2006a) emphasises the role of external audit and internal review to ensure

International Journal of Management and Applied Research, 2019, Vol. 6, No. 4 
Shariah compliance but it overlooks the importance of innovation.

Bank Negara Malaysia (2010) has developed a Shariah governance framework to provide guidance to the management of IFIs and Shariah boards in discharging duties and matters relating to Shariah. The framework is divided into six sections: 1) essential key functions; 2) accountability and responsibility; 3) independence; 4) competency; 5) confidentiality and consistency; 6) Shariah compliance and research functions. Besides emphasising the competency of Shariah board members and consistency of interpretation, the framework also highlights the importance of the Shariah board being independent from management.

The Shariah governance framework provided by Bank Negara Malaysia illustrates lines of command and four key functions to ensure Shariah compliance and innovation in Islamic banking. The board of directors is accountable to shareholders and the public, even though they are not directly controlling the key functions (risk management, audit, review and research). These key functions have their own direct and indirect line of reporting. While risk management is the first line of defence in Shariah governance, the compliance oversight function is the second line of defence and independent assurance is the third. Such multiple lines of defence strengthen financial consumer protection. The roles and responsibilities of each key element are outlined in the following:

- Board of Director: set and enforce clear lines of duties besides overseeing all operations;

- Management: ensure all operations are in accordance with Shariah law and provide necessary support to Shariah board ;

- Shariah Committee: accountable for all Shariah related matters;

- Shariah Risk Management: identify, measure, monitor and control Shariah non-compliance events;

- Shariah Review: review operations on a regular basis;

- Shariah Audit: provide independent assessment and objective assurance;

- Shariah Research: conduct in-depth research relating to Shariah

\section{Islamic Banking in Bangladesh}

There are eight fully-fledged Islamic banks which operate in Bangladesh. The first Islamic bank in Bangladesh is Islami Bank Bangladesh Limited which became incorporated in 1983. Following the success of Islami Bank, several Islamic banks were established, these include: 1) Al Baraka Bank was created in 1987; 2) Al-Arafah Islami Bank and 3) Social Investment Bank were established in 1995; 4) First Security Islami Bank Limited was founded in 1999; 5) Shahjalal Islami Bank was formed in 2001; 6) Exim Bank started a fully fledged Islamic bank in 2004; and lastly, 7) Union Bank

International Journal of Management and Applied Research, 2019, Vol. 6, No. 4 
Limited was formed in 2013.

\subsection{History of Islamic Banking in Bangladesh}

After the declaration of independence of Bangladesh in 1971, a number of initiatives were taken to form Islamic banks in the country. In 1974, Bangladesh signed the Charter of the Islamic Development Bank and as a member country, Bangladesh was committed to transform its conventional banking system into a Shariah-compliant banking system (Chowdhury et al., 2016). Apart from that, Bangladesh also privatised banks to liberalise the financial sector and encourage private investment and, in mid 1990s, a Financial Sector Reform Programme was implemented to improve banking operations through skills training and technological development (Rahman and Ara, 2009). The establishment of IBBL in 1983 begins the Islamic banking era (Ullah and Khanam, 2018).

\subsection{Legislative Framework of Islamic Banking in Bangladesh}

In Bangladesh, there is no specific law that guides and control the operations of IFIs. Like other financial institutions and banks, IFIs in Bangladesh are governed by the Bangladesh Bank Order 1972, the Income Tax Ordinance 1984, the Bank Companies Act 1991, the Companies Act 1994 and the Securities and Exchange Commission Act 1993.

The central bank of the country, Bangladesh Bank, has legal authority to regulate all banks in Bangladesh, including Islamic banks. It regulates prudential matters such as setting minimum capital requirements, limits on loan concentration and statutory liquidity ratios (Ahmad and Hassan, 2007). Bangladesh Bank published Guidelines for Conducting Islamic Banking in 2009 which is supplementary to the existing banking laws in the country. In the case of contradiction, the instructions issued under the Companies Act and Banking Companies Act will prevail (Bangladesh Bank, 2009, p. 1). The guidelines primarily focus on product definition, operational framework and alternative investment modes. There is no Shariah advisory council or board at Bangladesh Bank. The operations of IFIs in Bangladesh are scrutinised by the central bank as per the general rules set for non-Islamic banks. Table 1 summarises the financial regulators and institutions in Bangladesh, which regulate and monitor both conventional and Islamic institutions.

Table 1: Financial regulatory authorities in Bangladesh

\begin{tabular}{ll}
\hline \multicolumn{1}{c}{ Regulatory body } & \multicolumn{1}{c}{ Scope } \\
\hline Bangladesh Bank (Central Bank of Bangladesh) & Regulate banks and financial institutions \\
Securities and Exchange Commission & Regulate capital market \\
Insurance Development \& Regulatory Authority & Regulate insurance companies \\
Microcredit Regulatory Authority & Regulate microcredit institutions \\
\hline
\end{tabular}

International Journal of Management and Applied Research, 2019, Vol. 6, No. 4 
Over the years, Bangladesh Bank had granted several favourable treatments to support the development of Islamic banking in Bangladesh. For example, Islamic banks in Bangladesh are required to maintain their statutory liquidity ratio at $5.5 \%$ daily while it is $13 \%$ daily for conventional banks (Bangladesh Bank, 2014). Additionally, Islamic banks were permitted to fix their profit sharing ratio independently, corresponding to their organisational policy and Shariah law (Ahmad and Hassan, 2007). Bangladesh Bank also initiated the Islamic Inter-bank Fund Market and revised the Islamic bond rules to allow Islamic banks manage liquidity efficiently.

Nonetheless, more efforts are needed in order to enhance the regulatory framework of the banking system in Bangladesh. The shortcomings of the regulatory framework in ensuring Shariah compliance will be discussed in the next section.

\section{Current Practice of Shariah Governance in Bangladesh}

According to the guidelines published by Bangladesh Bank (2009, p. 10): "It will be the responsibility of the board of directors of the respective banks to ensure that the activities of the banks and their products are Shariah compliant" and "The Board may form an independent Shariah Supervisory Committee with experienced and knowledgeable persons in Islamic Jurisprudence". In other words, the board of directors would be held accountable for Shariah non-compliance and it is optional for the board to form an independent Shariah Supervisory Committee. However, the guidelines did not specify what sort of legal actions the central bank could take if an IFI is found to be violating Shariah law.

In some Muslim-majority countries, the appointment of Shariah scholars is mandatory before introducing Islamic financial products. In Indonesia for example, all Islamic Banks are required to have a Shariah board. Sole (2007) stated that new Islamic financial products cannot be introduced without prior approval from the Shariah board. The Central Shariah Board for Islamic Banks of Bangladesh (CSBIB) was formed in 2001 to offer advice for Islamic bankers in the country. However, IFIs are not obliged to follow their advice. Islamic banking in Bangladesh is regulated by the central bank but the central bank does not have a dedicated supervisory or advisory board to advise on Shariah matters. Because of the absence of strict monitoring, not all IFIs in Bangladesh comply with Shariah law (Ullah, 2014) and most of them do not conform to the Shariah principles of keeping customers as partners in profit or loss (Chowdhury et al. 2016).

In a case study of Islami Bank Bangladesh Limited (IBBL), Ullah and Khanam (2018) found that the favourable financial performance of IBBL was largely driven by Shariah compliance. Not all Islamic banks in Bangladesh comply with Shariah law, however.

International Journal of Management and Applied Research, 2019, Vol. 6, No. 4 
Ullah (2014) evaluated four selected Islamic banks in Bangladesh and concluded that Shariah compliance varies among the selected Islamic banks because of a shortage of knowledgeable auditors, lack of institutional framework and inadequate commitment to Shariah compliance.

\section{Challenges to Shariah Governance}

To compete with the conventional banks in the digital economy, IFIs have to adapt their functioning in line with modern banking practices. IFIs across the globe face challenges to Shariah governance of varying degrees, but mostly at the organisational level. In Bangladesh, however, IFIs face challenges to Shariah compliance at all levels.

\subsection{Lack of regulatory framework}

The legal and political environment which IFIs operate can introduce market distortions and undermine subsequent accountability. As a regulator of the Islamic banks, Bangladesh Bank plays a minimal role in Shariah compliance. The absence of an Islamic Banking Act and a national Shariah board to ensure Shariah compliance affects the standardisation of Shariah boards in each IFI. The Guidelines for Conducting Islamic Banking provided by Bangladesh Bank in 2009 serves as guidelines, not as rigid rules and regulations. The lack of institutional support for Shariah compliance leads to it being a low priority for management to comply with Shariah law (Ullah, 2014).

\subsection{Interest-based economy}

In a survey of 334 personnel of the Islamic banks in Bangladesh, the majority of the research respondents (88\%) considered the interest-based economy of Bangladesh as one of the major impediments to Shariah compliance (Ullah, 2014). Although Bangladesh Bank gives preferential treatment to IFIs in terms of liquidity, the central bank adheres to economic orthodoxy. Islamic banking in Bangladesh is nearly 40 years old and its Islamic investment instruments are comparatively less developed than those of the non-Islamic, mainstream financial industry. In a comparative study of Islamic and conventional banks in Bangladesh, Miah and Sharmeen (2015) concluded that Islamic banks are less cost-effective than their conventional counterparts. Facing competition from the conventional banks, Islamic banks in Bangladesh adopt a more "flexible" (Islam, 2017) approach towards Shariah compliance.

Another area that requires further attention is the Islamic capital market, which is still in its infancy in the country. Equally, the equity market in Bangladesh is quite small compared to its neighbouring countries (IFSB, 2014). A well-developed Islamic capital market would attract capital inflows from other Islamic countries thereby contributing towards economic growth and national development.

International Journal of Management and Applied Research, 2019, Vol. 6, No. 4 


\subsection{Lack of Shariah Scholars}

Shariah scholars play an important role in ensuring that IFIs are conforming to Shariah law. In Bangladesh, there is a shortage of Shariah scholars who understand and who can uphold the main pillars of Shariah governance. The central bank of Bangladesh has issued selection criteria for Shariah scholars but it is very difficult to recruit Shariah scholars based on those criteria. Among those criteria are that a candidate should have a minimum of three years experience in teaching or conducting research in Islamic finance in addition to a postgraduate qualification in Islamic studies and good knowledge of the Arabic language. On top of that, to be a member of a Shariah supervisory committee, a candidate should have a minimum of 3 years experience as a member of any fatwa board issuing Shariah resolutions for Islamic financial matters. This criterion naturally rules out any scholars who have not been appointed as member of Shariah committee before.

Furthermore, there is an absence of proper institutional arrangements for training Shariah scholars. In Bangladesh, courses related to Islamic banking and finance are quite limited. Except distance learning providers, no degree related to Islamic banking and finance is currently offered by any university in Bangladesh. Independent University in Bangladesh offers a banking course which introduces both conventional and Islamic banking. A UK-based professional body, Chartered Institute of Management Accountants (CIMA), offers an Islamic finance course in Bangladesh. Nevertheless, Ullah (2014) found that many managers of IFIs in Bangladesh were not well trained regarding Islamic finance.

\subsection{Lack of Government Supports}

Even though Bangladesh is a Muslim country, the government is not supportive enough to create an Islamic economic system in the country. Government support is particularly needed to introduce and implement an Islamic Banking Act (Ahmad and Hassan, 2007). Government policy has been enabling financial liberalisation in Bangladesh (Rahman and Ara, 2009). After liberation, there was noticeable economic growth and more importantly, expansion of bank business both in terms of volume and dimension (Ahmad and Hassan, 2007). However, government support for Islamic banking in Bangladesh has been low (Ahmad and Hassan, 2007; Islam, 2017; The Economist, 2019).

\section{Conclusion and Recommendation}

Shariah governance is one of the core elements of the Islamic financial system. There is a need to reform the current Shariah practices among the IFIs in Bangladesh. Bank Negara Malaysia (2010) provided a holistic view of the Shariah governance framework which could be used in the context of Bangladesh. At national level, the absence of a single authority to govern, monitor and standardise Shariah practices is a worrying sign.

International Journal of Management and Applied Research, 2019, Vol. 6, No. 4 
Each IFI has its own Shariah committee which may have differing standards. A national Shariah advisory council could help to monitor and assess Shariah compliance in all IFIs, which would act as a line of defence at the institutional level. It is crucial to point out that an Islamic financial system includes banking, insurance and the capital market. Hence, the Bangladesh government should take a more supportive role to strengthen its Islamic finance infrastructure.

The shortage of Shariah experts also needs to be addressed by providing necessary training and education. As a Muslims-majority nation, the academic curriculum related to Islamic banking and finance should be given more attention, not only for the purpose of training new generations of Shariah scholars, but also to encourage continuous professional development among existing Shariah scholars.

At an industry level, the Central Shariah Board for Islamic Banks of Bangladesh (CSBIB) could do more than just providing advisory services to IFIs in Bangladesh. CSBIB could empower managers and potential members of Shariah committee by providing training courses related to Islamic banking, organising examination to assess their knowledge and accrediting them if they pass. Furthermore, CSBIB could also offer external audits for IFIs to maintain Shariah compliance, certifying the IFIs if no Shariah violation is found. Accreditation and certification are a form of quality assurance which also serves as a line of defence for Shariah compliance.

The first and foremost line of defence for Shariah compliance lies with the organisational policy and internal control system. Before an IFI introduce a new Islamic financial product to the Bangladesh market, the IFI should seek advice and approval from knowledgeable Shariah scholars. Scholars, in turn, should conduct in-depth research regarding the product in terms of Shariah compliance. Moreover, there should be a Shariah risk management unit in place to identify the potential risks of Shariah non-compliance events and identify solutions to mitigate them. It is equally important to have an internal audit unit to assess operations regularly to make sure that all activities adhere to Shariah law.

To sum up, there is a room for improvements for IFIs in Bangladesh with regard to Shariah governance. With the right policies and timely action, the Islamic banking sector could continue to grow in the country.

\section{References}

1. Ahmad, A. U. and Hassan, M. K. (2007), "Regulation and performance of Islamic banking in Bangladesh", Thunderbird International Business Review, Vol. 49, No. 2 , pp. 251-277. https://doi.org/10.1002/tie.20142

International Journal of Management and Applied Research, 2019, Vol. 6, No. 4 
The Practice of Shariah Governance in Islamic Banking and Finance: A Study of Islamic Banks in Bangladesh

2. Allchin, J. (2015), "Grameen Bank set to go under full government oversight", Financial Times, [Online] Available from: https://www.ft.com/content/b237b790-b50f-11e4-b186-00144feab7de[Accessed on 1 June 2019].

3. Bangladesh Bank (2009), Guidelines for Conducting Islamic Banking, Dhaka: Bangladesh Bank.

4. Bangladesh Bank (2014), DOS Circular No.-01: Cash Reserve Ratio (CRR) and Statutory Liquidity Ratio (SLR), Dhaka: Bangladesh Bank.

5. Bank Negara Malaysia (2010), Guidelines on Shariah Governance Framework for Islamic Financial Institutions, Kuala Lumpur: Bank Negara Malaysia.

6. Chowdhury, M.; Shoyeb, M.; Akbar, C. and Islam, M. N. (2016), "Risk Sharing Paradigm of Islamic Banks: Case of Bangladesh", in: Mutum, D. S.; Butt, M. and Rashid, M. (ed.) Advances in Islamic Finance, Marketing, and Management, Emerald Publishing Group, pp. 103-130. https://doi.org/10.1108/978-1-78635-899-820161007

7. Claessens, S. (2006), "Corporate Governance and Development", The World Bank Research Observer, Vol. 21, No. 1, pp. 91-122, https://doi.org/10.1093/wbro/lkj004

8. Grais, W. and Pellegrini, M. (2006a), Corporate Governance and Shariah Compliance in Institutions Offering Islamic Financial Services, World Bank Policy Research Working Paper 4054, Washington D.C.: World Bank [Online] Available from:

https://openknowledge.worldbank.org/bitstream/handle/10986/8901/wps4054.pdf;s eq [Accessed on 1 June 2019].

9. Grais, W. and Pellegrini, M. (2006b), Corporate Governance in Institutions Offering Islamic Financial Services: Issues and Options, World Bank Policy Research Working Paper 4052, Washington D.C.: World Bank [Online] Available from: https://openknowledge.worldbank.org/bitstream/handle/10986/9030/wps4052.pdf;s equence $=1$ [Accessed on 1 June 2019].

10. Grassa, R. and Matoussi, H. (2014), "Corporate governance of Islamic banks", International Journal of Islamic and Middle Eastern Finance and Management, Vol. 7 No. 3, pp. 346-362. https://doi.org/10.1108/IMEFM-01-2013-0001

11. Haqqi, A. (2014), "Shariah governance in Islamic financial institution: An International Journal of Management and Applied Research, 2019, Vol. 6, No. 4 
The Practice of Shariah Governance in Islamic Banking and Finance: A Study of Islamic Banks in Bangladesh

appraisal”, US-China Law Review, Vol. 11, No. 1, pp. 112-133.

12. Hassan, Z. (2011), "A survey on Shariah governance practices in Malaysia, GCC countries and the UK critical appraisal", International Journal of Islamic and Middle Eastern Finance and Management, Vol. 4 No. 1, pp. 30-51. https://doi.org/10.1108/17538391111122195

13. International Monetary Fund (2018), The Core Principles for Islamic Finance Regulations and Assessment Methodology, https://www.imf.org/ /media/Files/Publications/PP/2018/pp040618the-core-princip les-for-islamic-finance-regulations.ashx [accessed on 6 June 2019].

14. Islam, S. (2017), The 'flexible' Shariah practice of Islamic banking in Bangladesh, Dharka Tribute, [Online] available from: https://www.dhakatribune.com/business/banks/2017/10/30/flexible-shariah-practic e-islamic-banking-bangladesh/ [accessed on 5 May 2019].

15. Islamic Financial Services Board (IFSB) (2009), Guiding principles on Shari'ah governance systems for institutions offering Islamic financial services. Kuala Lumpur: IFSB.

16. Islamic Financial Services Board (IFSB) (2014), Prospects and Challenges in the Development of Islamic Finance for Bangladesh. Kuala Lumpur: IFSB.

17. Kirkpatrick, G. (2008), The corporate governance lessons from the financial crisis, Paris: OECD.

18. Joh, S. W. (2003), "Corporate governance and firm profitability: evidence from Korea before the economic crisis", Journal of financial Economics, Vol. 68, No. 2, 2003, pp. 287-322. https://doi.org/10.1016/S0304-405X(03)00068-0

19. Johnson, S.; Boone, P.; Breach, A.; Friedman, E. (2000), "Corporate governance in the Asian financial crisis", Journal of Financial Economics, Vol. 58, No. 1-2, pp. 141-186. https://doi.org/10.1016/S0304-405X(00)00069-6

20. Karim, R. A. A. and Archer, S. (2011), Islamic Finance: The Regulatory Challenge, Singapore: John Wiley \& Sons.

21. Miah, M. D. and Sharmeen, K. (2015), "Relationship between capital, risk and efficiency", International Journal of Islamic and Middle Eastern Finance and Management, Vol. 8 No. 2, pp. 203-221.

International Journal of Management and Applied Research, 2019, Vol. 6, No. 4 
The Practice of Shariah Governance in Islamic Banking and Finance: A Study of Islamic Banks in Bangladesh

https://doi.org/10.1108/IMEFM-03-2014-0027

22. OECD (2014), Risk Management and Corporate Governance, Corporate Governance, OECD Publishing. https://doi.org/10.1787/9789264208636-en

23. Rahman, M. M. and Ara, L. A. (2009), "Trade in financial services in developing countries: a case of the Bangladesh financial sector", Journal of International Trade Law and Policy, Vol. 8 No. 2, pp. 114-136.

https://doi.org/10.1108/14770020910981461

24. Sole, J. (2007), Introducing Islamic Banks into Conventional Banking Systems International Monetary Fund, International Monetary Fund [Online] available from: https://www.imf.org/external/pubs/ft/wp/2007/wp07175.pdf [accessed on 5 May 2019].

25. The Economist (2019), "After the coup Islami Bank Bangladesh has declined since a boardroom coup in 2017", The Economist, [Online] available from: https://www.economist.com/finance-and-economics/2019/04/06/islami-bank-bangl adesh-has-declined-since-a-boardroom-coup-in-2017 [accessed on 5 May 2019].

26. Ullah, M. H. (2014), "Shari' ah compliance in Islamic banking: An empirical study on selected Islamic banks in Bangladesh", International Journal of Islamic and Middle Eastern Finance and Management, Vol. 7, No. 2, pp. 182-199. https://doi.org/10.1108/IMEFM-06-2012-0051

27. Ullah, M. H. and Khanam, R. (2018), "Whether Shari' ah compliance efficiency is a matter for the financial performance", Journal of Islamic Accounting and Business Research, Vol. 9 No. 2, pp. 183-200. https://doi.org/10.1108/JIABR-01-2016-0001

International Journal of Management and Applied Research, 2019, Vol. 6, No. 4 